\title{
IDENTIFIKASI KUALITAS PERMUKIMAN KUMUH MENGGUNAKAN METODE CASE BASE REASONING DAN FUZZY K-NEAREST NEIGHBOR (Studi Kasus: Kelurahan Kota Bengkulu)
}

\author{
(telp: 0736-341022; fax: 0736-341022)

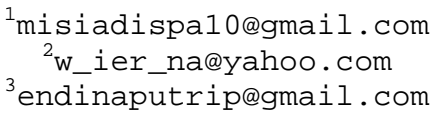

Misia Dispa Bainamus ${ }^{1}$, Ernawati ${ }^{2}$, Endina Putri Purwandari ${ }^{3}$

${ }^{1,2,3}$ Program Studi Teknik Informatika, Fakultas Teknik, Universitas Bengkulu. Jl. W.R. Supratman Kandang Limun Bengkulu 38371A INDONESIA

\begin{abstract}
Abstrak. Permukiman kumuh merupakan keadaan lingkungan hunian dengan kualitas yang tidak layak huni. Permukiman yang baik dan sehat merupakan kebutuhan dasar manusia dan adalah hak warga negara Indonesia. Permasalahan permukiman kumuh di Indonesia sudah harus diidentifikasi dan ditangani, khususnya pada wilayah perkotaan. Pemerintah melalui RPJMN tahun 2015-2019 membuat program pengentasan permukiman kumuh perkotaan menjadi tidak ada yaitu Kota Tanpa Kumuh (KOTAKU). Terdapat 67 kelurahan di Kota Bengkulu, dengan 7 indikator, dan 19 sub indikator penentu kualitas permukiman kumuh. Selanjutnya akan di identifikasi menjadi tingkat pemukiman kumuh tinggi, sedang, rendah atau tidak kumuh. Metode yang digunakan yaitu metode CBR dan untuk mencari similarity menggunakan metode Fuzzy KNN. Berdasarkan hasil penelitian didapatkan bobot yang sesuai untuk identifikasi pada sistem ini adalah 0,5, 1,5, 3,5, dan 5,5 dengan hasil persentase yang diperoleh adalah $82,08 \%$.
\end{abstract}

Kata Kunci: Permukiman kumuh, KOTAKU (Kota Tanpa Kumuh), Case Base Reasoning, Fuzzy KNN, Identifikasi

\begin{abstract}
Slum is the state of residential environment quality is not livable. The settlements are good and healthy is a basic human need and it is the right citizens of Indonesia. The problem of slums in Indonesia had to be identified and addressed, especially in urban areas. The government in 2015-2019 through RPJMN make urban slum eradication program be nothing namely Cities Without Slums (KOTAKU). There are 67 villages in the city of Bengkulu, with 7 indicators and 19 subindicators determine the quality of the slums. The next will be in the identification of high-level slums, medium, low or not seedy. The method used is the method of CBR and to look for similarity using Fuzzy KNN. Based on the results, appropriate weight to the identification of this sistem is $0.5,1.5,3.5$, and 5.5 with the results obtained percentage was $82.08 \%$.
\end{abstract}

Keywords: Slums, KOTAKU(Cities Without Slums), Case Base Reasoning, Fuzzy k-nearest neighbor, Identification.

\section{PENDAHULUAN}

Permukiman kumuh merupakan keadaan lingkungan hunian dengan kualitas yang sangat tidak layak huni [1]. Salah satu cara yang dilakukan untuk menangani kumuh adalah dengan mencegah dan meningkatkan kualitas perumahan dan permukiman kumuh guna meningkatkan mutu kehidupan dan penghidupan masyarakat. Pemerintah melalui Rencana Pembangunan Jangka Menengah Nasional Tahun 2015-2019 membuat target nasional pada sektor perumahan dan 
permukiman yang dituangkan dalam Peraturan Presiden Nomor 2 tahun 2015 tentang RPJMN 2015-2019, yaitu pengentasan permukiman kumuh perkotaan menjadi tidak ada [2].

Untuk mendukung kebijakan pemerintah tersebut, kota Bengkulu juga akan melakukan pengidentifikasian permukiman berdasarkan tingkatannya. Di Kota Bengkulu mempunyai 67 kawasan pemukiman yang tersebar menjadi 67 kelurahan, Untuk menentukan tingkatan permukiman tersebut diperlukan 8 indikator, dan ada 19 sub indikator. Hal inilah yang akan menentukan 67 kawasan permukiman yang ada di Kota Bengkulu, termasuk tingkat pemukiman kumuh tinggi, sedang, rendah atau tidak kumuh. Maka dari itu diperlukan sistem untuk mengidentifikasi kawasan permukiman kumuh yang ada di Kota Bengkulu.

Berdasarkan penelitian terkait dapat dilihat bahwa sistem yang akan dibuat ini menggunakan metode Case Base Reasoning, karena pada penelitian sebelumnya menggunakan metode ini akurasi yang di dapatkan baik. Penelitian ini juga menggunakan metode Fuzzy K- Nearest Neighbor ( untuk mencari kemiripan kasus data sebelumnya karena metode ini mencari jarak atau kemiripan terdekat dan dapat dilihat persentase kemiripannya. Prinsip kerja K-Nearest Neighbor (KNN) adalah mencari jarak terdekat antara data yang akan dievaluasi dengan K-Nearest Neighbor terdekatnya dalam data pelatihan.

Didasari juga oleh pola permukiman yang konsisten dimana setiap permukiman akan ada kondisi kekumuhan yang akan ditinjau berdasarkan indikator terkait dengan identifikasi yang dilakukan sehingga menghasilkan kondisi tingkat kekumuhan yang ada pada daerah yang ingin dilihat. Sesuai dengan konsep CBR metode ini berfungsi untuk mengambil informasi dari kasus yang lama untuk solusi kasus yang ada. Dalam implementasinya algoritma CBR yang digunakan untuk mencari kemiripan kasus adalah algoritma Fuzzy K-Nearest Neighbor (FKNN). Identifikasi yang akan dilakukan untuk mengetahui tingkat kondisi kekumuhan suatu Kelurahan seKota Bengkulu, maka penulis mengajukan proposal Identifikasi Kualitas Permukiman Kumuh Menggunakan Metode Case Base Reasoning dan Fuzzy K-Nearest Neighbor (Studi Kasus: Kelurahan se-Kota Bengkulu). Penelitian ini diharapkan dapat digunakan sebagai salah satu cara untuk dapat mempermudah pemerintah dalam mengidentifikasi dan melakukan penanganan terhadap kawasan permukiman kumuh di Kota Bengkulu.

\section{LANDASAN TEORI}

\section{A. Identifikasi Permukiman Kumuh}

Identifikasi permukiman kumuh dilakukan dengan cara memasukkan nilai yang di tanya oleh sistem, maka sistem akan melakukan pengolahan data sesuai dengan rumus atau pedoman yang di tetepkan oleh Tim KOTAKU. Adapun rumus pengolahan data tersebut dapat ditunjukkan pada persamaan 2.1 sampai 2.7.

Rumus $1=\mathrm{An}-\mathrm{A}_{\mathrm{n}}=\frac{H}{A_{n}} \times 100$

Rumus $2=\frac{A_{n}-A_{n}}{A_{n}} \times \mathrm{A}_{\mathrm{n}}=\frac{H}{A_{n}} \times 100$

Rumus $3=\frac{A_{n}-A_{n}}{A_{n}} x\left(\mathrm{~A}_{\mathrm{n}}-\mathrm{A}_{\mathrm{n}}\right)=\frac{H}{A_{n}} x 100$

Rumus $4=\frac{A_{n}}{A_{n}} \times \mathrm{A}_{3}=\frac{H}{A_{n}} \times 100$

Rumus $5=\mathrm{An}-\mathrm{An}=\frac{H}{A_{n}} \times 100$

Rumus $6=\frac{A_{n}}{A_{n}} x\left(\mathrm{~A}_{\mathrm{n}}-\mathrm{An}\right)=\frac{H}{A_{n}} x 100$

Keterangan:

A = Angka yang diinputkan, atau dimasukkan ke sistem

$\mathrm{H}=$ Hasil yang didapat dari perhitungan

$\mathrm{n}=1,2,3,,,,, \mathrm{n}$ (inputan ke-n) [2]. 


\section{B. KOTAKU (Kota Tanpa Kumuh)}

Program Kota Tanpa Kumuh (KOTAKU) adalah program pencegahan dan peningkatan kualitas permukiman kumuh nasional yang merupakan penjabaran dari pelaksanaan Rencana Strategis Direktorat Jenderal Cipta Karya tahun 2015 - 2019. Sasaran program ini adalah tercapainya pengentasan permukiman kumuh perkotaan menjadi 0 Ha. Kualitas permukiman kumuh adalah Data jalan lingkungan; kondisi bangunan; drainase; air bersih/minum; pengelolaan persampahan; pengelolaan air limbah; pengamanan kebakaran.

\section{Case Based Reasoning (CBR)}

Case Base Reasoning (CBR) merupakan sebuah sistem yang menggunakan pengalaman lama untuk dapat mengerti dan menyelesaikan masalah baru [3]. Tahapan proses sistem penalaran komputer berbasis kasus:

\section{Retrieve}

Retrieve adalah proses mencari kasus yang serupa dengan kasus yang tersimpan dalam basis data, serta memunculkan solusi yang relevan.

\section{Reuse}

Proses pemilihan informasi apa saja dari kasus sebelumnya yang dapat digunakan sekarang.

\section{Revise}

Revise adalah proses evaluasi dilakukan, mengkalkulasi dan mempertimbangkan solusi kasus dari proses sebelumnya, jika solusi berhasil dijalankan maka proses berlanjut ke proses retain.

\section{Retain}

Retain adalah proses penyaringan sebuah informasi dari kasus dan solusi yang baru yang akan disimpan ke dalam basis data.

\section{Fuzzy K-Nearest Neighbor}

Algoritma K-Nearest Neighbor merupakan algoritma yang melakukan klasifikasi berdasarkan kedekatan lokasi atau jarak suatu data dengan data yang lainnya [4]. Algoritma ini digunakan ketika melakukan reuse pada metode Case Base Reasoning, Adapun rumus dari algoritma ini ditunjukkan pada Persamaan 2.7.

similarity $=\frac{\left(s_{1} \times w_{1}\right)+\left(s_{2} \times w_{2}\right)+\cdots+\left(s_{n} \times w_{n}\right)}{w_{1}+w_{2}+\cdots+w_{n}}$

Keterangan :

$s_{n}=$ nilai kemiripan, yaitu ketika sama (1) dan beda (0).

$w_{\boldsymbol{n}}=$ weight (bobot yang diberikan).

\section{METODOLOGI}

Langkah-langkah yang dilakukan dalam penelitian ini adalah :

1) Studi Pustaka

Studi pustaka dilakukan dengan cara menelaah beberapa literatur, yaitu:

a) Buku

Buku yang digunakan sebagai referensi adalah buku yang membahas tentang permukiman kumuh,dan metode case base reasoning dan fuzzy serta pendekatannya.

b) Jurnal

Jurnal yang digunakan diperoleh dari jurnal yang terkait dengan penelitian ini dengan cara di cari melalui internet. Informasi yang diperoleh adalah informasi yang membahas tentang identifikasi permukiman kumuh dan metode CBR dan Fuzzy KNN.

2) Studi Lapangan

Metode ini dilakukan dengan cara cara mendatangi TIM KOTAKU dibagian pengolahan data permukiman kumuh di kota bengkulu. Data yang dibutuhkan untuk penelitian ini adalah data kelurahan dan indikator terkait permukiman kumuh. 


\section{ANALISIS DATA DAN PERANCANGAN}

\section{A. Analisis Data}

Pada penelitian ini data yang diperoleh merupakan data dari hasil survei yang dilakukan oleh TIM KOTAKU pada tahun 2016. Permukiman yang digunakan adalah 67 kelurahan di Kota Bengkulu.

1. Data identifikasi

Data identifikasi, ada 7 indikator dan 19 sub indikator. Sub indikator ini nanti dijadikan pertanyaan ketika identifikasi dilakukan, ada 4 jawaban masing-masing sub indikator serta semua jawaban tersebut juga ada bobotnya masingmasing. Tingkat kumuh ditentukan dari penjumlahan bobot yang di dapatkan dari jawaban yang dimasukkan. Nilai penentuan tingkat kumuh adalah Kumuh Berat (71-95), Kumuh Sedang (4570), Kumuh Ringan (19-44) dan Tidak Kumuh (018) [2].

\section{Data Sample}

a. Kasus Lama

Pada kasus lama di metode Case Base Reasoning didapat kasus lama sebanyak 4 kasus, yaitu pada kelurahan Sumur Dewa, Pekan Sabtu, Penurunan, Betungan. Kelurahan ini terdiri dari setiap kondisi dari kasus lama tahun sebelumnya. Keempat kelurahan tersebut dipilih oleh TIM KOTAKU, karena berdasarkan sample yang dilihat dari tahun sebelumnya kasus tersebut cenderung stabil.

\section{b. Validasi}

Validasi kasus baru dilakukan oleh admin atau operator TIM KOTAKU, karena mereka yang bisa menentukan kasus tersebut sudah bisa dijadikan base case atau masih di kasus baru.

\section{Analisis Sistem}

Analisis sistem adalah bagian dari penelitian yang menganalisis sistem yang ada, dimana fungsinya adalah untuk merancang sistem baru atau memperbaharui sistem yang suda ada. Diagram alir (flowchart) dari keseluruhan sistem ditunjukkan pada Gambar1.

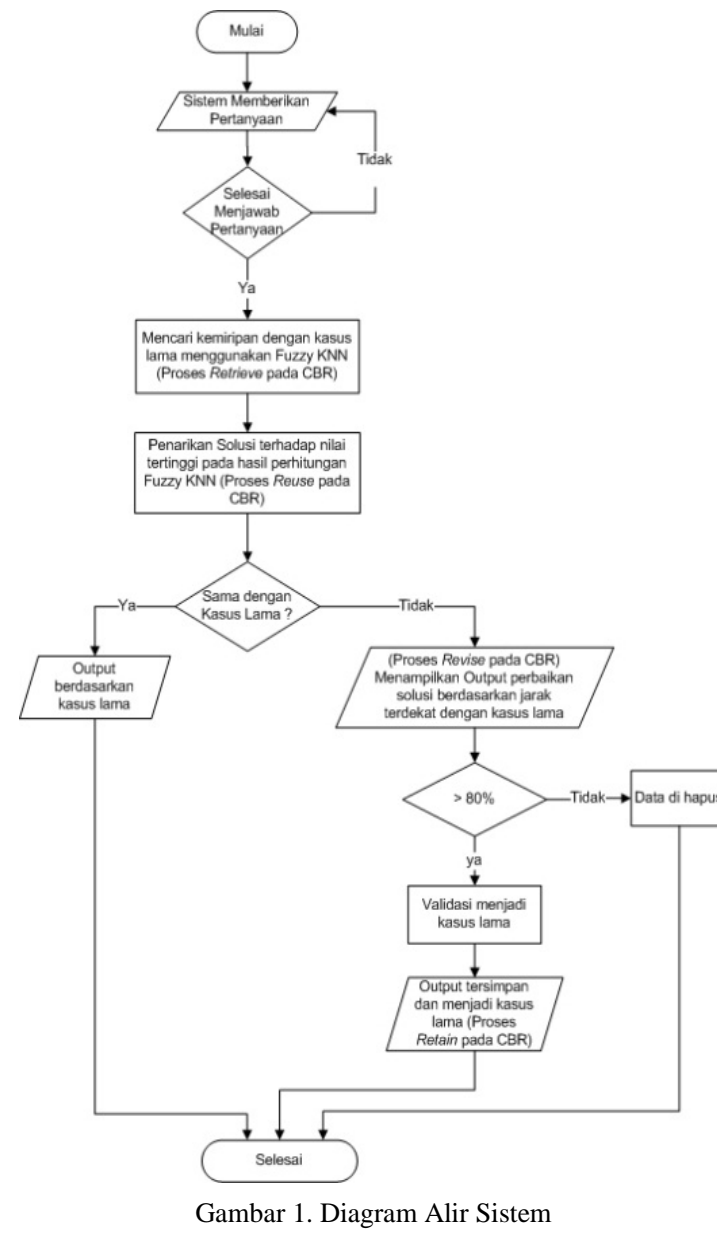

\section{B. Perancangan Sistem}

Perancangan sistem dalam sistem pakar ini terdiri dari beberapa bagian, yaitu percangan Unified Modeling Language (UML).

\section{1) Use Case Diagram}

Pada sistem ini terdapat dua orang pengguna, yaitu admin dan user. User disini dapat melihat total identifikasi, melihat seluruh permukiman yang ada di Kota Bengkulu seperti, kecamatan, kelurahan dan RT. Admin berfungsi untuk 
manajemen kecamatan, kelurahan RT, Kasus baru, kasus lama, pertanyaan, jawaban dan indikator.Untuk lebih jelasnya dapat dilihat pada Gambar 2.

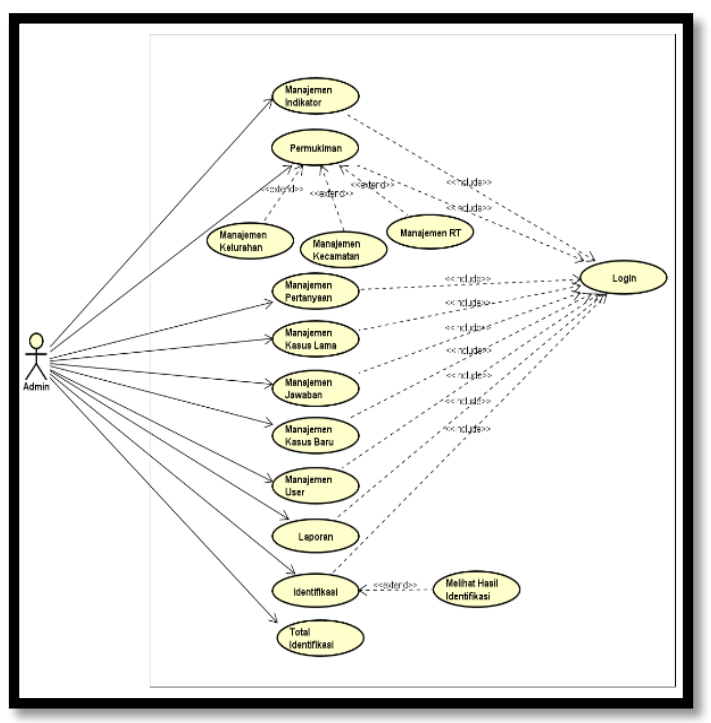

Gambar 2. Diagram Use Case

2) Class Diagram

Class Diagram pada sistem identifikasi kualitas permukiman kumuh di Kota Bengkulu ini dapat dilihat pada Gambar 3.

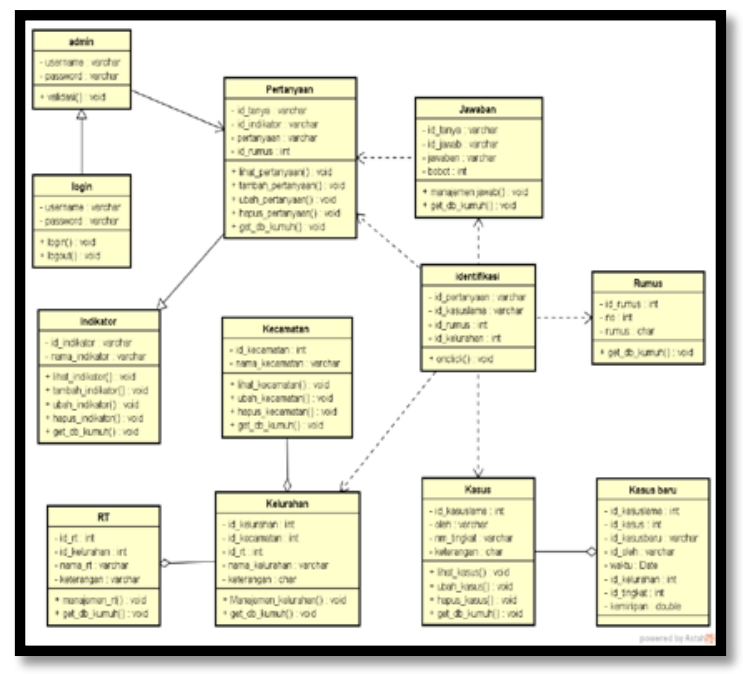

Gambar 3. Class Diagram

\section{PEMBAHASAN}

\section{A. Implementasi Antarmuka}

Pada tahapan implementasi antar muka ini, sistem akan diimplementasikan menggunakan bahasa pemrograman PHP dan menggunakan framework Codeigniter.

1. Halaman Home

Halaman home pada sistem ini adalah halaman yang pertama kali dijalankan. Berikut adalah tampilan dari halaman utama sistem yang ditunjukkan pada Gambar 4.

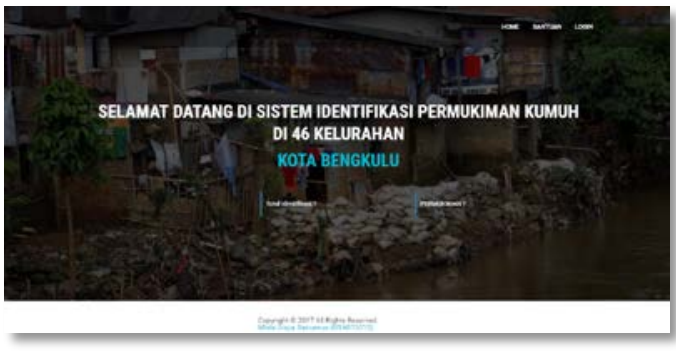

Gambar 4. Halaman Home

Dapat dilihat pada Gambar 4 merupakan tampilan halaman home yang merupakan halaman yang pertama kali diakses ketika membuka sistem. Halaman home ini berisi tentang ucapan selamat datang dan ada tombol total identifikasi dan permukiman.

\section{Halaman Login Admin}

Halaman login adalah sebuah halaman yang digunakan untuk masuk ke halaman khusus Admin, dimana pada halaman Admin, Admin dapat melakukan semua hal yang tidak bisa dilakukan oleh pengguna biasa, seperti mengelola kasus, mengelola kasus baru, mengelola permukiman, indikator, pertanyaan, dan melakukan identifikasi. Berikut adalah tampilan halaman login yang ditunjukkan pada Gambar 5.

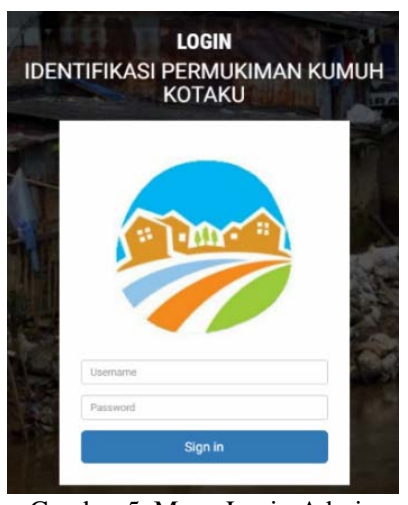

Gambar 5. Menu Login Admin 


\section{Halaman Home Admin}

Halaman home Admin adalah halaman yang pertama kali diakses setelah halaman login oleh Admin. Pada halaman ini akan menampilkan beberapa total data dari pertanyaan, permukiman,kasus baru, kasus lama, dan sebagainya. Berikut adalah tampilan dari halaman home Admin yang ditunjukkan pada Gambar 6.
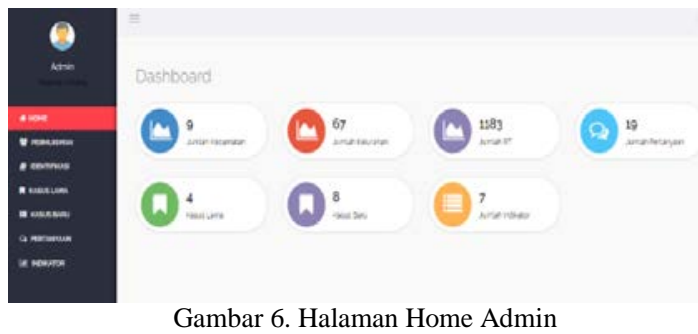

\section{Halaman Menu Identifikasi}

Halaman Pada Halaman Menu Identifikasi ini menampilkan pilihan nama admin yang ingin melakukan identifikasi dan kelurahan mana yang ingin di identifikasi permukimannya. Lalu juga ada tombol untuk memulai identifikasi, yang akan menampilkan pertanyaa. Berikut adalah tampilan
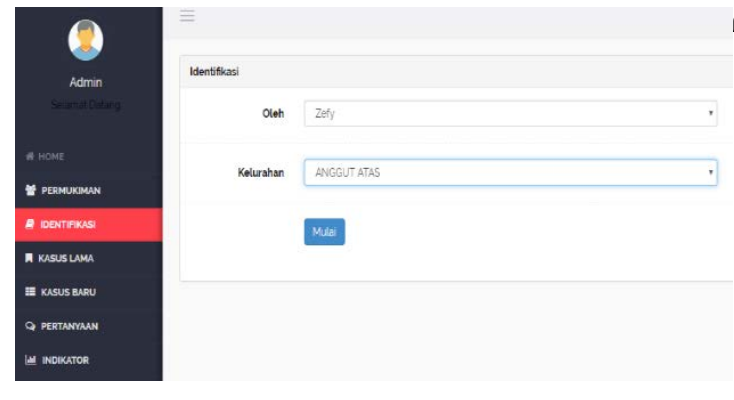

Gambar 7. Halaman Menu Identifikasi

5. Halaman Identifikasi Pertanyaam

Pada halaman menu identifikasi ini akan tampil apabila kita telah menekan tombol mulai pada Gambar 7. Halaman ini menampilkan pertanyaanpertanyaan yang sesuai dengan indikator permukiman kumuh. Admin akan memasukkan data secara dan sistem akan memproses data tersebut untuk menjadi persentasi jawaban yang sesuai dengan apa yang dimasukkan. Halaman menu identifikasi ditunjukkan pada Gambar 8.

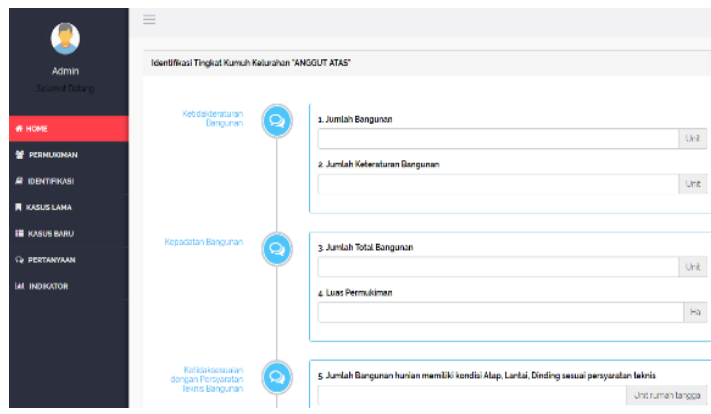

Gambar 8. Halaman Identifikasi Pertanyaan

6. Halaman Hasil Identifikasi

Halaman hasil identifikasi ini merupakan halaman hasil apa yang admin dapatkan ketika selesai melakukan identifikasi. Identifikasi yang yerlah dilakukan sebelumnya akan menghasilkan jawaban tingkat kumuhnya pada halaman ini. Berikut adalah tampilan dari halaman hasil identifikasi yang ditunjukkan pada Gambar 9.
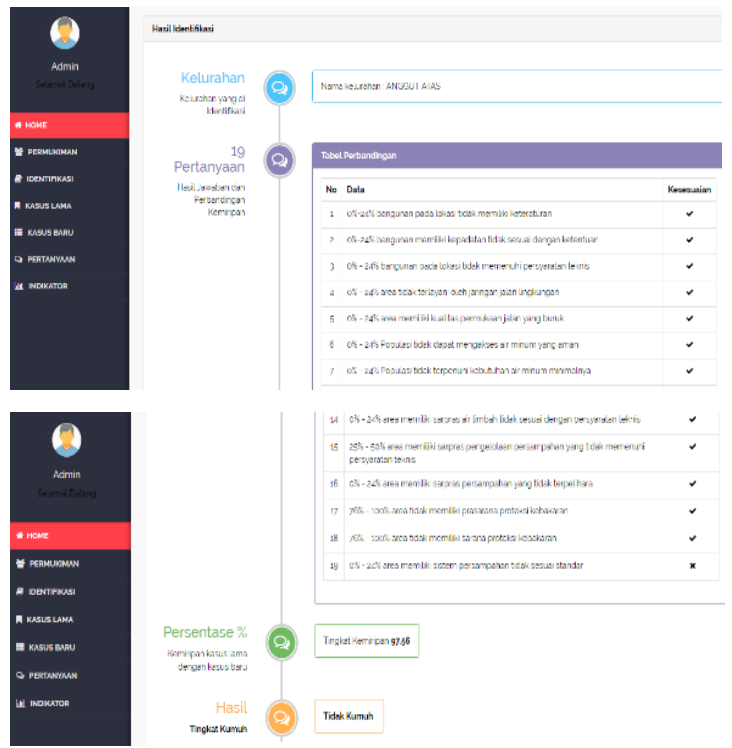

Gambar 9. Halaman Hasil Identifikasi

\section{Halaman Kasus Baru}

Halaman kasus baru ini merupakan hasil kasus yang didapatkan dari hasil identifikasi yang dilakukan pada halaman identifikasi. Berikut adalah tampilan dari halaman menu kasus baru yang ditunjukkan pada Gambar 10. 


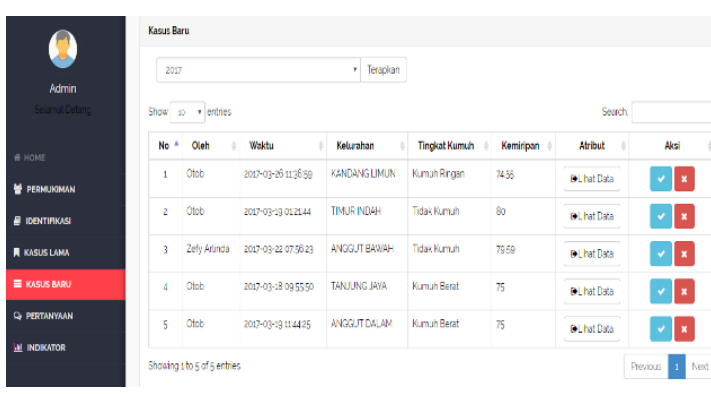

Gambar 10. Halaman Kasus Baru

\section{B. Pengujian Sistem}

\section{Pengujian White Box}

Adapun pengujian white box dalam menguji metode Case Base Reasoning untuk Identifikasi Kualitas Permukiman Kumuh ini adalah sebagai berikut ini.

1) Flow Graph

Berikut adalah notasi flow graph metode case base reasoning yang digunakan:

1: at_kasuslama = berdasarkan kasus lama

2: inisialisasi

\$atas $\quad=0$;

\$bawah =0;

\$distance $=0$;

\$jml $=0$;

\$persen =0;

\$sama $=\operatorname{array}()$;

\$beda = array () ;

\$j $\quad=0$;

3: for $\mathrm{i}=0$

4: $\$ \mathrm{i}<$ count $\left(\$ a t \_k a s u s b a r u\right)=$ kasus baru berdasarkan kasus lama

5: if (\$at_kasusbaru[\$j]['id_jawab'] ==

\$at_kasuslama[\$i]['id_jawab']) //CBR menggunakan KNN

6: \$nilai $=1$;

\$sama[]=array(\$at_kasusbaru[\$j]['id_jawab']);

7: else

8: \$nilai =0; // ketika perbandingan

menghasilkan data yang berbeda

\$beda[] = array(\$at_kasusbaru[\$j]['id_jawab']);
9: endif

10: perhitungan knn

atas $+=($ \$nilai*\$at_kasusbaru[\$j]['bobot']);

bawah += \$at_kasusbaru[\$j]['bobot'];

jml += \$nilai //perbandingan kasus lama dan

baru

$\$ \mathrm{j}++$;

11: endfor

12: Inisialisasi

$\$ \mathrm{j}=0$;

13: hitung hasil knn

\$distance $=$ round $(($ \$atas/\$bawah)*100,2)

14: Perbandingan kasus

\$persen = round $(((\$ j m l / 19) * 100), 2) ;$

15: \$urut = simpan hasil \$distance dan $\$$ persen

16: foreach ( \$urut as \$param => \$row)

\$id[\$param] = Mengurutkan hasil

perhitungan dilihat $\mathrm{dr}$ id

\$jarak[\$param] = Mengurutkan hasil

perhitungan berdasarkan jarak

17: endforeach

18: \$tingkat = cek tingkat berdasarkan kasus lama // CBR

19: update kasus baru = array(id_kasuslama, id_tingkat, kemiripan)

20: if kasus_baru $==$ valid validasi // CBR

21: kasus_baru $=$ kasus

22: $\quad$ else

23 kasusbaru

24: $\quad$ endif

Berikut pada gambar adalah gambar flow graph metode Case Based Reasoning dan metode fuzzy K-nearest neighbor yang digunakan ditunjukkan pada gambar 11. 


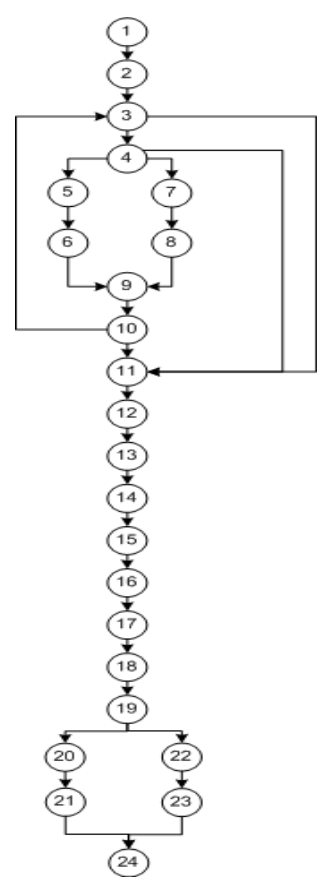

Gambar 11. Flow Graph

Dari Gambar 11 diketahui bahwa alur eksekusi sistem menunjukkan 5 jalur berbeda yang disebut dengan independent path. Berikut adalah independent path yang di dapat.

a. 1-2-3-4-7-8-9-10-11-12-13-14-15-16-17-18$19-22-23-24$

b. 1-2-3-4-5-6-9-10-11-12-13-14-15-16-17-1819-20-21-24

C. 1-2-3-11-12-13-14-15-16-17-18-19-20-21-24

d. 1-2-3-11-12-13-14-15-16-17-18-19-22-23-24

e. 1-2-3-4-11-12-13-14-15-16-17-18-19-20-21-24

\section{2) Basis Path}

Setelah mendapatkan independent path, berikut adalah tabel basis path testing metode Case Based Reasoning yang ditunjukkan pada Tabel 1.

\begin{tabular}{|c|c|c|c|}
\hline No & Path & Kondisi & Hasil \\
\hline 1 & $\begin{array}{l}1-2-3-4-7-8- \\
9-10-11-12- \\
13-14-15-16- \\
17-18-19-22- \\
23-24\end{array}$ & $\begin{array}{l}\text { Path ini dijalankan } \\
\text { bersasarkan kondisi atribut } \\
\text { kasus baru yang } \\
\text { dimasukkan pengguna } \\
\text { tidak sama dengan kasus } \\
\text { lama yang tersimpan dalam } \\
\text { database dan kasus baru } \\
\text { yang dimasukkan } \\
\text { pengguna divalidasi oleh }\end{array}$ & Berhasil \\
\hline
\end{tabular}

\begin{tabular}{|c|c|c|c|}
\hline & & $\begin{array}{l}\text { admin untuk menjadi kasus } \\
\text { lama. }\end{array}$ & \\
\hline 2 & $\begin{array}{l}1-2-3-4-5-6- \\
9-10-11-12- \\
13-14-15-16- \\
17-18-19-20- \\
21-24\end{array}$ & $\begin{array}{l}\text { Path ini dijalankan } \\
\text { bersasarkan kondisi atribut } \\
\text { kasus baru yang } \\
\text { dimasukkan pengguna } \\
\text { sama dengan kasus lama } \\
\text { yang tersimpan dalam } \\
\text { database karena sama } \\
\text { maka atribut tersebut } \\
\text { bernilai satu, dan kasus } \\
\text { tersebut divalidasi oleh } \\
\text { admin }\end{array}$ & Berhasil \\
\hline 3 & $\begin{array}{l}1-2-3-11-12- \\
13-14-15-16- \\
17-18-19-20- \\
21-24\end{array}$ & $\begin{array}{l}\text { Path ini dijalankan untuk } \\
\text { menghitung jarak } \\
\text { kemiripan yang terjadi } \\
\text { setelah perbandingan } \\
\text { kasus. Lalu melakukan } \\
\text { pengurutan data dari id } \\
\text { berdasarkan jarak, jika } \\
\text { valid maka akan divalidasi } \\
\text { oleh admin. }\end{array}$ & Berhasil \\
\hline 4 & $\begin{array}{l}1-2-3-11-12- \\
13-14-15-16- \\
17-18-19-22- \\
23-24\end{array}$ & $\begin{array}{l}\text { Path ini dijalankan untuk } \\
\text { menghitung jarak } \\
\text { kemiripan yang terjadi } \\
\text { setelah perbandingan } \\
\text { kasus. Lalu melakukan } \\
\text { pengurutan data dari id } \\
\text { berdasarkan jarak, jika } \\
\text { tidak valid maka akan } \\
\text { tersimpan dikasus baru. }\end{array}$ & Berhasil \\
\hline 5 & $\begin{array}{l}1-2-3-4-11- \\
12-13-14-15- \\
16-17-18-19- \\
20-21-24\end{array}$ & $\begin{array}{l}\text { Path ini dijalankan ketika } \\
\text { untuk mengulang kondisi } \\
\text { atribut kasus baru sama } \\
\text { dengan kasus lama maka } \\
\text { perulangan berakhir dan } \\
\text { hasilnya sama dengan } \\
\text { kasus lama. }\end{array}$ & Berhasil \\
\hline
\end{tabular}

\section{Pengujian Black Box}

Berikut adalah kasus untuk menguji perangkat lunak yang telah dibangun menggunakan metode black box. Metode ini berhasil melakukan pengecekan terhadap fungsi yang tidak benar atau hilangm kesalahan antarmuka, kesalahan dalam struktur data atau akses database eksternal, dan kesalahan kinerja. Pada pengujian ini telah didapatkan hasil 100\% kebenaran sistem, mulai dari tidak ada kesalaham antar muka, sistem dan lain sebagainya.

1. Pengujian Kelayakan Sistem a. Terhadap bobot $0,5,1,5,3,5,5,5$ 
Jurnal Pseudocode, Volume IV Nomor 1, Februari 2017, ISSN 2355-5920

www.ejournal.unib.ac.id/index.php/pseudocode

\begin{tabular}{|c|c|c|c|c|c|c|}
\hline \multirow[t]{2}{*}{ No } & \multirow[t]{2}{*}{ Pertanyaan } & \multicolumn{5}{|c|}{ Bobot Jawaban } \\
\hline & & $\begin{array}{c}\text { Kasus lama (1) } \\
\text { Kumuh Berat }\end{array}$ & $\begin{array}{l}\text { Kasus lama (2) } \\
\text { Kumuh Sedang }\end{array}$ & $\begin{array}{l}\text { Kasus lama (3) } \\
\text { Kumuh Ringan }\end{array}$ & $\begin{array}{c}\text { Kasus lama (4) } \\
\text { Tidak Kumuh }\end{array}$ & Kasus Baru (1) \\
\hline 1 & Ketidakteraturan Bangunan & 5,5 & 0,5 & 1,5 & 0,5 & 0,5 \\
\hline 2 & Kepadatan Bangunan & 0,5 & 0,5 & 0,5 & 0,5 & 0,5 \\
\hline 3 & $\begin{array}{l}\text { Ketidaksesuaian dengan } \\
\text { Persyaratan Teknis Bangunan }\end{array}$ & 5,5 & 1,5 & 0,5 & 0,5 & 0,5 \\
\hline 4 & $\begin{array}{l}\text { Cakupan Pelayanan Jalan } \\
\text { Lingkungan }\end{array}$ & 3,5 & 0,5 & 0,5 & 0,5 & 0,5 \\
\hline 5 & $\begin{array}{l}\text { Kualitas Permukaan Jalan } \\
\text { lingkungan }\end{array}$ & 3,5 & 3,5 & 3,5 & 0,5 & 0,5 \\
\hline 6 & $\begin{array}{l}\text { Ketersediaan Akses Aman } \\
\text { Air Minum }\end{array}$ & 5,5 & 3,5 & 1,5 & 0,5 & 0,5 \\
\hline 7 & $\begin{array}{l}\text { Tidak terpenuhinya } \\
\text { Kebutuhan Air Minum }\end{array}$ & 3,5 & 3,5 & 1,5 & 0,5 & 0,5 \\
\hline 8 & $\begin{array}{l}\text { Ketidakmampuan } \\
\text { Mengalirkan Limpasan Air }\end{array}$ & 5,5 & 5,5 & 0,5 & 0,5 & 0,5 \\
\hline 9 & Ketidaktersediaan Drainase & 3,5 & 0,5 & 0,5 & 0,5 & 0,5 \\
\hline 10 & $\begin{array}{l}\text { Ketidakterhubungan dengan } \\
\text { Sistem Drainase Perkotaan }\end{array}$ & 5,5 & 5,5 & 0,5 & 0,5 & 0,5 \\
\hline 11 & $\begin{array}{l}\text { Tidak terpeliharanya } \\
\text { Drainase }\end{array}$ & 1,5 & 3,5 & 0,5 & 0,5 & 0,5 \\
\hline 12 & Kualitas Konstruksi Drainase & 5,5 & 1,5 & 0,5 & 0,5 & 0,5 \\
\hline 13 & $\begin{array}{l}\text { Sistem Pengelolaan Air } \\
\text { Limbah Tidak Sesuai Standar } \\
\text { Teknis }\end{array}$ & 5,5 & 3,5 & 0,5 & 0,5 & 0,5 \\
\hline 14 & $\begin{array}{l}\text { Prasarana dan Sarana } \\
\text { Pengelolaan Air Limbah } \\
\text { Tidak Sesuai dengan } \\
\text { Persyaratan Teknis }\end{array}$ & 3,5 & 1,5 & 0,5 & 0,5 & 0,5 \\
\hline 15 & $\begin{array}{l}\text { Prasarana dan Sarana } \\
\text { Persampahan Tidak Sesuai } \\
\text { dengan persyaratan Teknis }\end{array}$ & 5,5 & 5,5 & 0,5 & 1,5 & 0,5 \\
\hline 16 & $\begin{array}{l}\text { Sistem Pengelolaan } \\
\text { Persampahan yang tidak } \\
\text { sesuai Standar Teknis }\end{array}$ & 5,5 & 3,5 & 3,5 & 5,5 & 3,5 \\
\hline 17 & $\begin{array}{l}\text { Tidakterpeliharanya Sarana } \\
\text { dan Prasarana Pengelolaan } \\
\text { Persampahan }\end{array}$ & 0,5 & 0,5 & 0,5 & 0,5 & 0,5 \\
\hline 18 & $\begin{array}{l}\text { Ketidaktersediaan Sarana } \\
\text { Proteksi Kebakaran }\end{array}$ & 5,5 & 5,5 & 5,5 & 5,5 & 5,5 \\
\hline 19 & $\begin{array}{l}\text { Ketidaktersediaan Prasarana } \\
\text { Proteksi Kebakaran }\end{array}$ & 5,5 & 5,5 & 5,5 & 5,5 & 5,5 \\
\hline
\end{tabular}

Kasus baru ini merupakan contoh data di kelurahan jalan gadang, hasil yang di dapat dari kemiripan pada tabel diatas di atas adalah kemiripan kasus baru terhadap kumuh berat ialah 77\%, kumuh rendah ialah 87\%, kumuh sedang ialah 72\%, tidak kumuh ialah 51\%. Pada pengujian yang dilakukan menggunakan 67 data kelurahan didapatkan hasil ada 1 data kelurahan yang memiliki persentase kemiripan yang sama.

b. Pengujian bobot berdasarkan kasus asli dibandingkan dengan bobot yang akan dicoba. Kesamaan dengan kasus yang asli inilah yang akan menentuan bobot mana yang akan digunakan pada sistem Identifikasi Permukiman Kumuh di Kota Bengkulu ini. Tabel pengujiannya dapat dilihat pada Tabel 3, yang merupakan contoh Data.

Tabel 3. Contoh Data

Pengujian bobot berdasarkan kasus asli ini

\begin{tabular}{|c|c|c|c|c|c|}
\hline 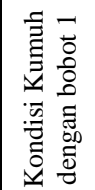 & 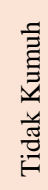 & 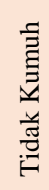 & 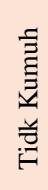 & 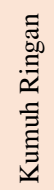 & 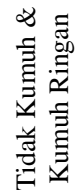 \\
\hline
\end{tabular}
dilakukan secara keseluruhan data, dan 


\begin{tabular}{|c|c|c|c|c|c|}
\hline 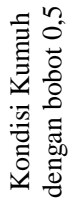 & 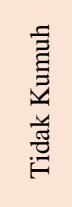 & 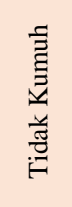 & 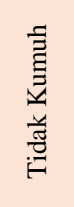 & 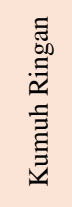 & $\begin{array}{l}\text { 品 } \\
\text { 品 } \\
\text { 志 } \\
\text { 茎 }\end{array}$ \\
\hline 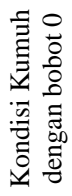 & 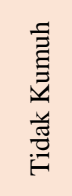 & 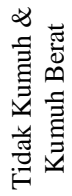 & 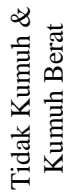 & 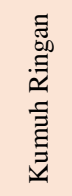 & 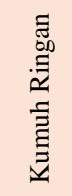 \\
\hline 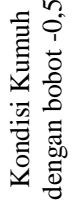 & 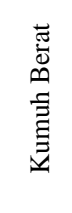 & 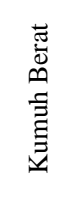 & 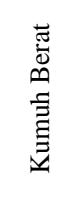 & 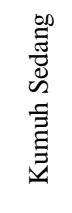 & 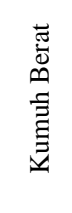 \\
\hline 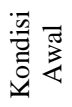 & 䔅声 & 莺声 & 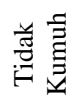 & 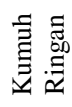 & 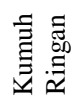 \\
\hline 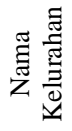 & 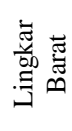 & 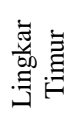 & 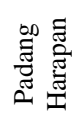 & 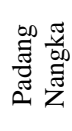 & 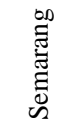 \\
\hline
\end{tabular}

Tabel diatas menunjukkan beberapa data

yang ada, dan percobaan dengan tambahan bobot dan pengurangan bobot. Ketika sama dengan kondisi atau kasus asli maka dapat dihat pada tabel yang berwarna merah muda. Berikut ini ada perhitungan persentase berdasarkan kemiripan dengan kasus yang asli.

1). Pengujian dengan bobot $-0,5,0,5,2,5,4,5$ :

Data yang berbeda dengan kondisi permukiman yang asli adalah 65 kasus data dari total 67 data. Data yang sama dengan kondisi permukiman yang asli adalah 2 kelurahan.

$$
\begin{gathered}
\text { * Jadi, } \frac{\text { data beda }}{\text { Jumlah data }} \times 100 \%=\frac{2}{67} \times 100 \% \\
=2,98 \%
\end{gathered}
$$

2). Pengujian dengan bobot $0,1,3,5$ :

Data yang berbeda dengan kondisi permukiman yang asli adalah 23 kasus data dari total 67 data. Data yang sama dengan kondisi permukiman yang asli adalah 44 kelurahan.
Jadi, $\frac{\text { data beda }}{\text { Jumlah data }} \times 100 \%=\frac{44}{67} \times 100 \%$ $=65,67 \%$

3). Pengujian dengan bobot 0,5, 1,5, 3,5, 5,5

Data yang berbeda dengan kondisi permukiman yang asli adalah 12 kasus data dari total 67 data. Data yang sama dengan kondisi permukiman yang asli adalah 55 kelurahan

$$
\text { * Jadi, } \begin{aligned}
\frac{\text { data beda }}{\text { Jumlah data }} \times 100 \% & =\frac{55}{67} \times 100 \% \\
& =82,08 \%
\end{aligned}
$$

4). Pengujian dengan bobot 1, 2, 4, 6

Data yang berbeda dengan kondisi permukiman yang asli adalah 20 kasus data dari total 67 data. Data yang sama dengan kondisi permukiman yang asli adalah 47 kelurahan

$$
\begin{aligned}
* \text { Jadi, } \frac{\text { data beda }}{\text { Jumlah data }} \times 100 \% & =\frac{47}{67} \times 100 \% \\
& =70,13 \%
\end{aligned}
$$

Berdasarkan pengujian yang telah dilakukan, didapatkan persentase tertinggi yaitu penggunaan bobot dengan penambahan 0,5 yaitu 0,5, 1,5, 3,5, 5,5, sebesar 82,08\%. Berdasarkan akurasi yang didapatkan sebesar 82,08\%, maka validasi sistem untuk proses penyimpanan ke kasus lama (base case) berdasarkan akurasi sistem ini.

\section{KESIMPULAN}

Berdasarkan hasil dan pembahasan yang telah dijabarkan sebelumnya, maka kesimpulan yang dapat diambil adalah sebagai berikut.

1. Penelitian ini telah berhasil melakukan identifikasi berdasarkan 7 indikator dan 19 sub indikator dari TIM KOTAKU. Dengan mengajukan pertanyaan dari 19 sub indikator tersebut, sistem dapat menentukan hasil tingkat kualitas permukiman kumuh dengan akurasi sebesar $82,08 \%$. 
2. Penelitian ini telah berhasil menerapkan metode Fuzzy K-Nearest Neighbor untuk mencari kemiripan kasus dalam proses reuse pada metode Case Base Reasoning dengan bobot 0,5, 1,5, 3,5, dan 5,5.

3. Penelitian ini berhasil membangun Sistem Identifikasi Permukiman Kumuh di Kota Bengkulu, dibuktikan dari pengujian bobot yang dilakukan dengan 67 data kelurahan seKota Bengkulu didapatkan hasil dengan bobot 0,5, 1,5, 3,5, dan 5,5 merupakan hasil paling dekat dengan hasil dari data asli atau data sebenarnya, dengan persentase sebesar $82,08 \%$.

\section{SARAN}

Berdasarkan analisa dan perancangan sistem, implementasi, dan pengujian sistem, maka saran yang dapat diberikan untuk pengembangan penelitian selanjutnya adalah sebagai berikut:

1. Data pada identifikasi permukiman ini harus memasukkan inputan banyak yang sesuai dengan data yang didapatkan dari TIM KOTAKU, hal ini kurang efektif jika salah memasukkan data maka hasilnya juga akan berbeda. Maka disarankan untuk mencoba menggunakan identifikasi dengan langsung memasukkan file atau lain sebagainya.

2. Kelemahan dari metode Case Base Reasoning ini adalah banyaknya data yang dibandingkan akan memakan waktu proses pencarian. Metode similarity yang digunakan juga mempengaruhi waktu pencarian. Untuk itu pada penelitian selanjutnya harus di perkirakan terlebih dahulu jumlah data dan metode yang digunakan. Metode lainnya yang bisa digunakan seperti collaborative filtering.

3. Pada metode similarity Fuzzy K-Nearest Neighbor yang digunakan, untuk pengembangan selanjutnya bobot yang diberikan harus sesuai dengan metode ini, jika tidak lebih baik menggunakan metode similarity yang lain. Seperti metode Cosine Similarity, atau Correlation-based similarity.

4. Kelemahan lainnya pada sistem ini adalah persentase dari kemiripan kasus yang kurang tinggi, maka dari itu untuk meningkatkan akurasi disarankan untuk adaptasi metode pada proses revise, seperti menggunakan genetic algorithm.

5. Base case yang digunakan pada sistem ini tergolong sedikit, oleh karena itu pada penelitian selanjutnya disarankan untuk menggunakan pengklasifikasian untuk mempermudah dan memperbanyak base case. Seperti metode Algoritma Hierarchical Clustering.

6. Pada sistem ini belum terdapat solusi dari hasil identifikasi yang di dapatkan karena setelah identifikasi dilakukan, maka sistem hanya mengkasilkan tingkat kumuh dari kelurahan yang diidentifikasi. Untuk penelitian selanjutnya disarankan menambahkan solusi penanganan yang prioritas terhadap permukiman yang terkategori kumuh, agar pada data selanjutnya kategori kumuh menjadi menurun.

\section{REFERENSI}

[1] N. F. d. R. P. Setiawan, "Identifikasi Karakteristik Lingkungan Permukiman Kumuh di Kelurahan Kapuk, Jakarta Barat," Jurnal Teknik Pomits, Vols. 3, No. 2, p 5, 2014.

[2] D. J. C. Karya, "Draft Petunjuk Pelaksanaan KOTAKU Tingkat Kota," 2016.

[3] T. H. L. K. R. R. W. Ria Chaniago, Prediksi Cuaca Menggunakan Metode Case Base Reasoning dan Adaptive Neuro Fuzzy Inference System INFERENCE SYSTEM, Vols. 12, No. 12, Bandung: Departemen Teknik Informatika Institut Teknologi Harapan Bangsa, 2014, p. 6.

[4] E. Prasetyo, Data Mining, Yogyakarta: Andi, 2012. 